\title{
Use of a mathematical model to estimate the impact of shrimp pen culture at Patos Lagoon estuary, Brazil
}

\author{
LUÍS H. POERSCH ${ }^{1}$, ÂNGELA M. MILACH ${ }^{1}$, RONALDO O. CAVALLI ${ }^{2}$, \\ WILSON WASIELESKY JR. ${ }^{1}$, OSMAR MÖLLER ${ }^{1}$ AND JORGE P. CASTELLO ${ }^{1}$ \\ ${ }^{1}$ Universidade Federal do Rio Grande/FURG, \\ Av. Italia, Km 8, Carreiros, 96201-900 Rio Grande, RS, Brasil \\ ${ }^{2}$ Universidade Federal Rural de Pernambuco/UFRPE, \\ Rua Dom Manoel de Medeiros, s/n, Dois Irmãos, 52171-900 Recife, PE, Brasil
}

Manuscript received on March 21, 2013; accepted for publication on October 14, 2013

\begin{abstract}
Ecological modeling has been used as a tool to estimate potential impacts caused by aquaculture to the surrounding environment. In this work, a mathematical model was applied to estimate the maximum amount of pink shrimp (Farfantepenaeus paulensis) culture units $\left(3,100 \mathrm{~m}^{2}\right.$ pen enclosures) that could be installed at two shallow estuarine bays of Patos Lagoon (known as Coreia and Porto do Rei) with no significant effects on either water quality or viability of the culture system. To calibrate the model, information about the culture of Litopenaeus vannamei and F. paulensis as well as field data (influence of netting material, water current speed and nitrogen concentrations) were used. Under a bad scenario (water current velocity of $0.01 \mathrm{~m} \mathrm{~s}^{-1}$ and a mesh clogging effect of $40 \%$ ), it would be possible to install up to 29 pens at the Coreia bay, and 39 pens at the Porto do Rei bay. Results indicate that the model was useful in determining the maximum number of culture units that could be installed at these bays, and thus have the potential to become an important tool in the definition of environmental management strategies in relation to aquaculture development.
\end{abstract}

Key words: nitrogen, pen shrimp culture, sustainability, ecological modeling, coastal management.

\section{INTRODUCTION}

Following the worldwide growth of shrimp farming in the last decades, there has been strong pressure for the development of environmentally sound and economically feasible shrimp culture systems (Funge-Smith and Briggs 1998). Although water quality is imperative for the development of aquaculture activities, the maintenance of

Correspondence to: Luís Henrique Poersch

E-mail:1poersch@mikrus.com.br environmental quality of the surrounding area is of paramount importance, and therefore care must be taken with the effluents as they can affect the sustainability of the activity (Bunting 2001). Water renewal may help in keeping acceptable water quality within the culture system, but since the effluents are rich in phosphates, nitrogenous compounds and organic matter, they may negatively affect the surrounding environment (Clark 1996). The increase of nutrients can cause phytoplankton 
blooms, accelerate eutrophication processes and place in danger not only the cultured species but also the adjacent aquatic environment (Burford et al. 2003).

Feeding is usually considered the main cause of pollutant in aquaculture since it is the main source of organic matter and nutrients (Goddard 1996). Decomposition of unconsumed feed and metabolic waste results in the increase of phosphorous and nitrogen concentrations (Viadeiro et al. 2005). Phosphorous and nitrogen play a key role in the dynamics of aquaculture systems because they could act as a source of nutrition but also as toxic compounds for the reared organisms (Lefebvre et al. 2001). The discharge of nitrogen compounds from culture systems into coastal waters is one of the major concerns related to aquaculture. Currently, due to the expressive growth of shrimp production, researchers identified that there is a need to evaluate the performance of aquaculture system in an integrated form, perhaps through systems dynamics. Furthermore, there are not enough reports about nitrogen processes and flows in different culture systems (Gómez-Galindo 2000). Some nitrogen dynamics models were developed to evaluate nitrogen flow in closed shrimp culture systems, like earthen ponds (Lorenzen et al. 1997, Hargreaves 1998, Montoya et al. 1999, JiménezMontealegre et al. 2002). However, few studies were carried out in open culture systems (Hall et al. 1992, Falconer and Hartnett 1993, Kishi and Uchiyama 1995, Castello et al. 2008).

Capture of the pink shrimp Farfantepenaeus paulensis at the Patos Lagoon estuarine area, Southern Brazil, is the main income for local artisanal fishermen (Reis et al. 1994). However, due mainly to overfishing, total catches have progressively declined during the last years, leading to severe socio-economic problems (D'Incao and Reis 2002, D'Incao et al. 2002). Thus, shrimp culture has come as an alternative to generate employment and additional income for fishermen communities (Wasielesky et al. 2004, Cavalli et al. 2008), especially if alternative, low investment culture systems are deployed. Among them, pen culture is a potential candidate as it presents several advantages in relation to the traditional pond culture systems, including high water renewal rates and lower installation costs (Cavalli et al. 2008). Culture in pen enclosures can be considered an environment friendly system as it reduces impacts and promotes social and economical development (Poersch 2004, Cavalli et al. 2008).

In this work, we used a mathematical model to estimate the maximum number of culture units (pen enclosures) that could be installed in shallow estuarine bays in Patos Lagoon without significantly affecting the water quality from the surrounding area, as well as the overall sustainability of the culture system.

\section{STUDY AREA}

The Patos Lagoon estuary has a water volume of approximately $1.65 \cdot 10^{9} \mathrm{~m}^{3}$ distributed over an area of $963.8 \mathrm{Km}^{2}$, which represents $11.3 \%$ of the total lagoon surface area (Poersch et al. 2007). The estuary can be divided in two major areas (Bonilha and Asmus 1994): a central water body with deep channels and several protected shallow bays, with depths ranging from of 0.5 to $3 \mathrm{~m}$ (Castello 1985).According to Seeliger and Kjerfve (2001), the main factors that determine the hydrodynamics of the Patos Lagoon estuary are fluvial discharge, tidal variation and wind regime. However, due to the low amplitude of tidal variation (mean of $0.30 \mathrm{~m}$ ), its influence is minor (Möller et al 2001). Patos Lagoon can be considered a river-dominated estuary (Möller et al. 2001, 2009). When river discharge is below average $\left(\sim 2400 \mathrm{~m}^{3} \mathrm{~s}^{-1}\right)$ winds are the main mechanism for driving the exchange between the lagoon and the coastal area. During periods of above-average discharge tied with the seasonal late winter peak or El Niño events, only strong southwest winds can force salty water to enter into the lagoon, which can become fresh for several months (Möller and Castaing 1999). River 
discharge also exerts a strong control on the interannual variability of pink shrimp production as demonstrated by the negative relationship between river discharge and shrimp production (Castello and Möller 1978, Möller et al. 2009).

One of the few studies on the hydrodynamics of the protected bays of Patos Lagoon estuary applied mathematical models to predict water circulation patterns (Monteiro et al. 2005).
The present study was carried out to estimate the maximum amount of pink shrimp culture units $\left(\sim 3000 \mathrm{~m}^{2}\right.$ pen enclosures) that could be installed at two distinct bays at the Patos Lagoon estuary, located near the island Ilha dos Marinheiros (Fig. 1). The Coreia bay (S $31^{\circ} 58^{\prime} 57.9^{\prime \prime} \mathrm{W} 52^{\circ} 09^{\prime} 16.9^{\prime \prime}$ ) has a mean water volume of $6.5 \times 10^{6} \mathrm{~m}^{3}$, while the Porto do Rei bay (S 32 00' 12.8' e W 52 06'05.3") presents a mean water volume of $8.72 \times 10^{6} \mathrm{~m}^{3}$.

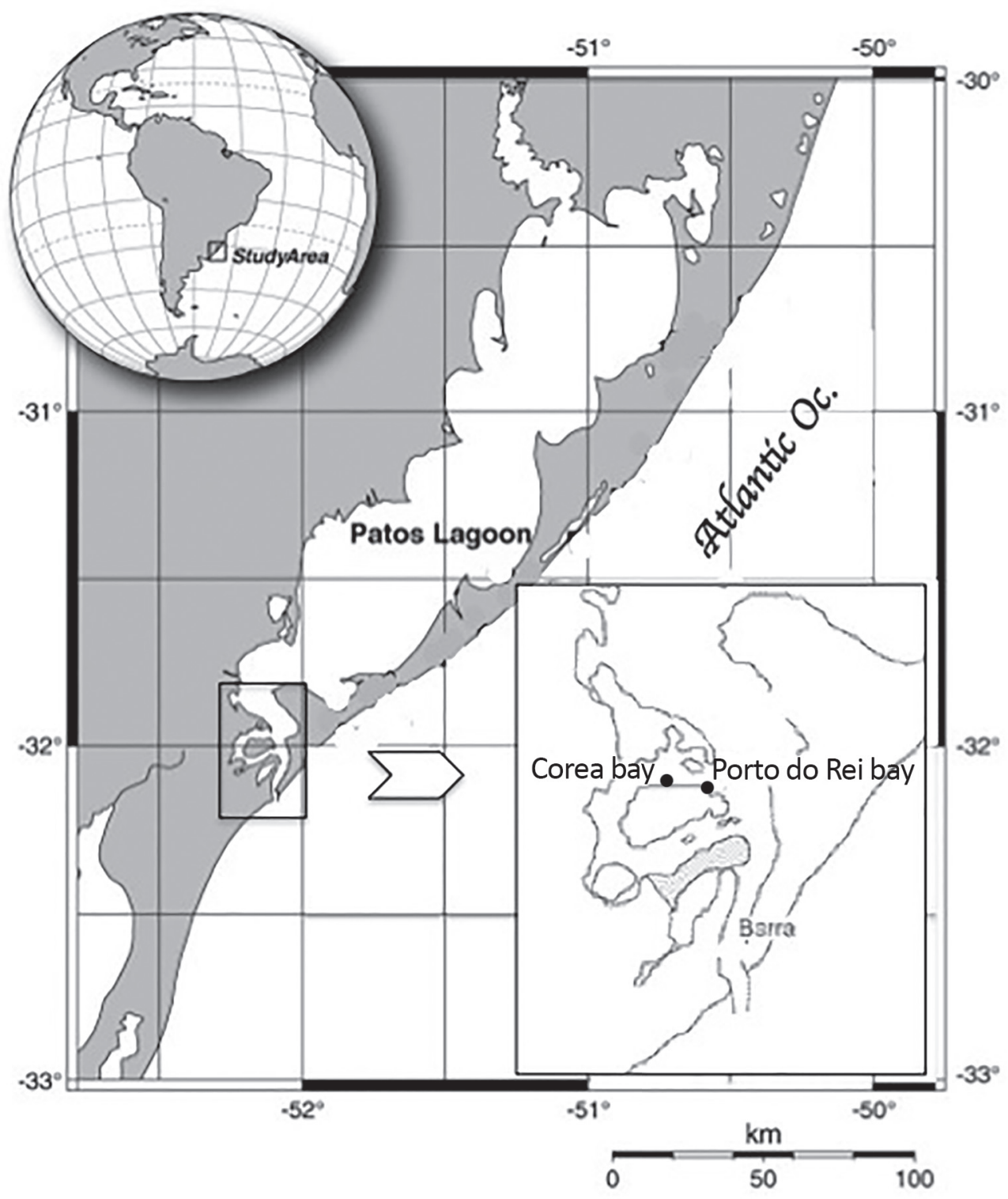

Figure 1 - Study area in the Patos Lagoon estuary, Southern Brazil: Coreia and Porto do Rei bays. 


\section{Shrimp CULture In PEN ENClosures}

Several aspects of the rearing of $F$. paulensis in pen enclosures have been studied in the last few years (Wasielesky et al. 2001, Poersch 2004, Cavalli et al. 2008). Under standard rearing conditions, 60,000 laboratory-reared PL30 (30 days old post-larvae) are acclimated to prevailing salinity levels and stocked in $200 \mathrm{~m}^{2}$ nursery pens, which are installed within a larger $\left(3000 \mathrm{~m}^{2}\right)$ grow-out enclosure. These are made of PVC-coated polyester nets with a mesh size of $5 \mathrm{~mm}$ (to assure constant water flow) and are sustained by bamboo poles in a circular manner. The production cycle usually lasts for 120 days - 30 days of nursery rearing followed by 90 days of growout. Shrimp were fed a commercial diet (Purina MR - $35^{\circledR}$ ), and fishery discards (crab, fish and shrimp) in a proportion of $30 \%$ diet and $70 \%$ fishery discards. Additionally, shrimp had access to natural food items (benthic organisms, biofilm and particulate suspended matter). Commercial diet and fishery discards were fed to the shrimp by hand three times a day. An initial feeding rate of $30 \%$ of the shrimp biomass was applied and reduced throughout the culture period to $2 \%$ of the total biomass. The stocking density was approximately $20 \mathrm{shrimp} / \mathrm{m}^{2}$.

\section{Conceptual Model}

The conceptual model (Fig. 2) was based on Odum (1983) and represents the processes of consumption and production of nitrogen that take place at the pen enclosure during the input, transformation and removal from the water column for a semi-intensive shrimp culture system. The model comprises the artificial diet and the natural food sources as unlimited external forces, which are the driving forces of the system. Dietary nitrogen content can be absorbed and assimilated by shrimp and thus converted into biomass. A portion of the nutrients from the diet is lost to the water column in the forms of feces and excretion; or may not be consumed at all, causing direct loss to the environment. The nitrogen present in natural food sources also contributes to the total input. The flows and interactions that occur among the system components are known as transference functions.

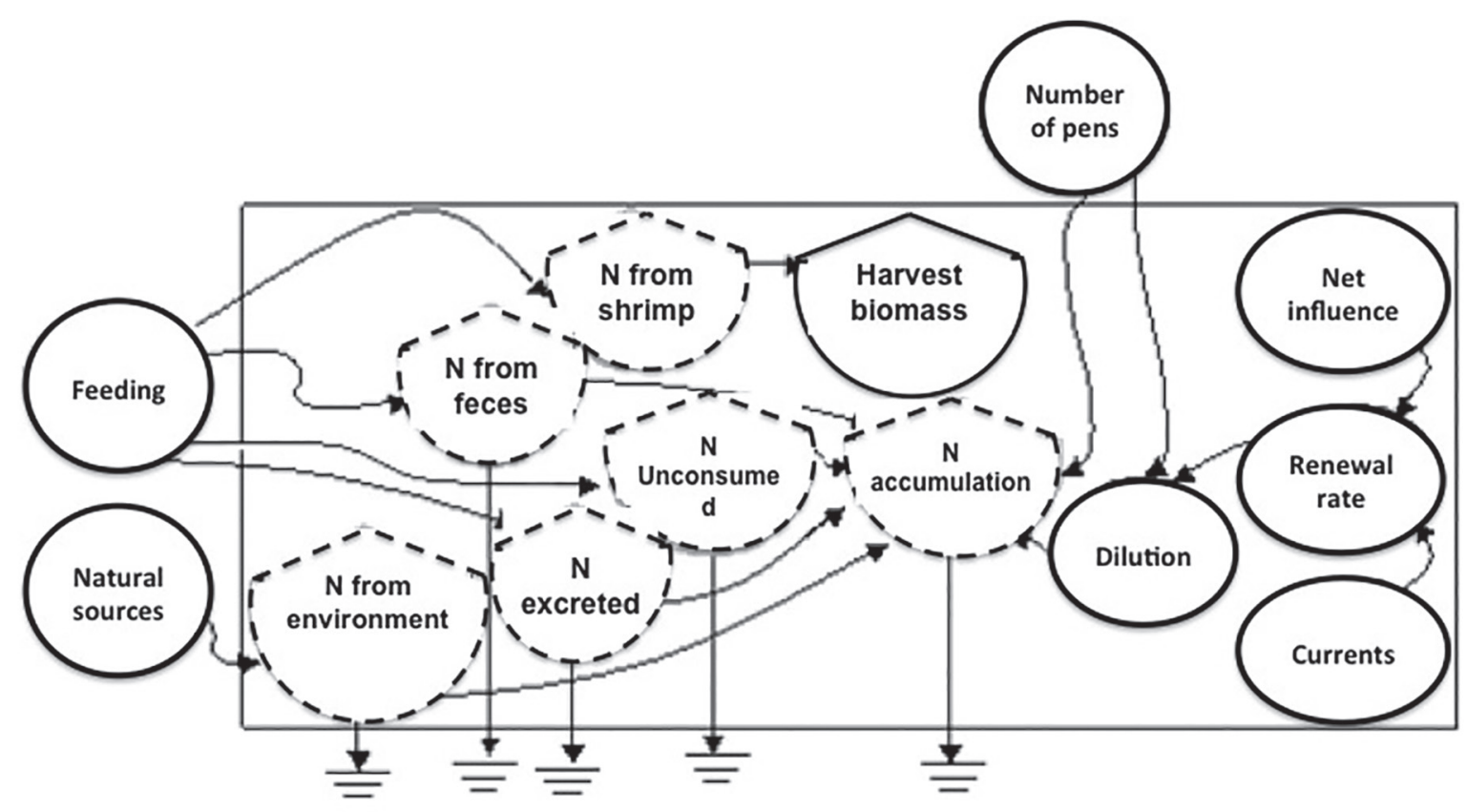

Figure 2 - Conceptual model of nitrogen input, transformation and removal from a semi-intensive shrimp pen culture system. 
Nitrogen released from the system accumulates in the surrounding aquatic environment, thus total nitrogen concentration is related to the number of culture units installed in a given area. The number of production units is considered an external control in the conceptual model. The dilution process may be considered a nitrogen accumulation control, dependent on the water renewal rate that, in turn, is determined by current velocity at the culture site and by the clogging effect of the net pen. These factors, which govern and give basis to define the dilution process, are denominated parameters.

\section{MODEL STRUCTURE}

The mathematical model was formed using the software STELLA ${ }^{\mathrm{TM}}$ (version 9.0.1, 2005). The model describes nitrogen flow in the aquatic environment through the interaction of the pen enclosure with the surrounding environment. Water current speed was determined in situ by the observation of drifting plastic bottles filled (90\%) with water from the culture site (Wasielesky 2000). Current speed was considered constant during 24 hours. Historical data of total nitrogen concentration was obtained from Poersch et al. (2007). The theoretical determination of nitrogen released from the culture system was based on shrimp growth, feeding rates and water samples, which indicate the nitrogen derived from unconsumed feed, feces and excretion (see the Appendix). Information used to calibrate the model was based on recent data on the culture of two shrimp species: Litopenaeus vannamei and $F$. paulensis.

It was assumed that:

- Nitrogen content of protein is equal to $16 \%$ (Lourenço et al. 2002). Thus, $1 \mathrm{Kg}$ of shrimp has $178.5 \mathrm{~g}$ of protein, which contains $28.56 \mathrm{~g}$ of nitrogen (Boyd and Teichert-Coddington 1995);

- The commercial diet $\left(\right.$ Purina $\left.^{\circledR}\right)$ contained 30\% crude protein;

- The feeding rate (FR) was the same applied by

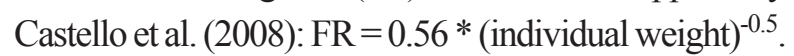
Adopting this rate, nitrogen sources that were potentially available to the environment (from feces, gill excretion and unconsumed feed) were determined;

- The amount of feed (QF) applied to a given pen was FR multiplied by the shrimp biomass stocked at that pen;

- A 15\% feed loss (unconsumed feed - NC), was estimated considering a semi-intensive culture system (Primavera 1993, Barbieri and Ostrensky 2002);

- The ingested feed (IN) was calculated as $\mathrm{IN}=\mathrm{QF}-\mathrm{NC}$;

- Since shrimp do not digest everything they consume, the digested food (DI) is transformed into growth (GR) and excretion (EX). The undigested food is transformed into feces (FC). Therefore, $\mathrm{FC}=\mathrm{IN}-\mathrm{DI}$ and $\mathrm{EX}=\mathrm{IN}-(\mathrm{FC}+\mathrm{GR})$;

- It was estimated that only $25 \%$ of the offered feed ingested by shrimp during the culture is transformed into biomass, i.e., growth (GR) and harvested biomass (Barbieri and Ostrensky 2002);

- Montoya et al. (1999) observed that for semipurified diets $90 \%$ of the protein is digested;

- Mortality rate during the culture period was $20 \%$;

- Initial shrimp weight (nursed juveniles) was $0.35 \mathrm{~g}$ (Wasielesky 2000);

- Initial number of shrimp stoked per pen ( $0.3 \mathrm{ha})$ was 60.000 (20 shrimp $\left./ \mathrm{m}^{2}\right)$.

After determining the total nitrogen released from a pen, a second step, integrating the pen to the aquatic environment, was performed. To estimate the maximum number of pens that would not affect the water quality in two culture sites (Porto do Rei and Coreia bays), a mathematical model was created assuming that:

- The influence of the netting material on the water flow was estimated as the difference between water current velocity measured inside and outside the pen (five meters away from the pen enclosure) installed at the Porto do Rei bay. Based on these measurements, a reduction of $20 \%$ of the water flow was assumed;

- Clogging of the net pens was considered to reduce water flow up to $40 \%$;

- Velocity of the water masses was measured throughout the culture period; 
- The limit for total nitrogen (N-NT) concentration that the system can support is $0.07 \mathrm{mg} \mathrm{L}^{-1}$ (Poersch et al. 2007);

- Total water volume of the bay was calculated considering the total surface area (software Cartalinx) and batimetry isobaths. As surface areas for Coreia and Porto do Rei bays were estimated to be $13 \mathrm{Km}^{2}$ and $10.9 \mathrm{Km}^{2}$, respectively, the total water volume was estimated in $6.5 \times 10^{6} \mathrm{~m}^{3}$ for Coreia and $8.72 \mathrm{x}$ $10^{6} \mathrm{~m}^{3}$ for Porto do Rei.

- Nitrogen retained at the bottom of the pens was released to the water column during harvest.

PHYSICO-CHEMICAL PARAMETERS

Every three days water temperature and salinity were measured at the culture sites. These parameters were affected by wind regime, which varied during the culture period. Nevertheless, Southern and Eastern winds were dominant during the culture period (FURG Meteorology Station).

Mean ( \pm sd) salinity and temperature levels during the experimental period at the Porto do Rei and Coreia bays were $21.9( \pm 2.4) 23.8^{\circ} \mathrm{C}( \pm 1.1)$, and $19.3( \pm 1.3)$ and $25.2^{\circ} \mathrm{C}( \pm 0.5)$, respectively. These values agree with the levels reported by Baumgarten and Niencheski (1990) for the Patos Lagoon estuary and are considered to be within the suitable range for F. paulensis (Wasielesky 1999).

ESTIMATIONS OF CURRENT VELOCITY AND WATER

RENEWAL RATES

The water current speed was measured outside the pens and at a control point one hundred meters from the pen enclosure. These values were measured for two months, and were used to determine the net influence.

For the Coreia bay, the lowest current velocity was $0.013 \mathrm{~m} \mathrm{~s}^{-1}$, which indicates that water was exchanged at least 11 times per day. In contrast, during the highest current velocity measured $\left(0.052 \mathrm{~m} \mathrm{~s}^{-1}\right)$ water was exchanged 82 times. At Porto do Rei, daily water renewal rates within the pen ranged from 28 to 50 exchanges.
Current speeds at the point outside the pen $(5 \mathrm{~m}$ from the pen) at Porto do Rei bay ranged from 0.007 to $0.047 \mathrm{~m} \mathrm{~s}^{-1}$, while at Coreia bay, they ranged from 0.013 to $0.052 \mathrm{~m} \mathrm{~s}^{-1}$. These current speeds are responsible for the dilution of the nitrogenous compounds originating from the culture pens.

At control points located $100 \mathrm{~m}$ away from the pen enclosure, current velocity ranged from 0.008 to $0.076 \mathrm{~m} \mathrm{~s}^{-1}$ at Porto do Rei, and from 0.047 to $0.12 \mathrm{~m} \mathrm{~s}^{-1}$ at the Coreia bay (Tab.1). Poersch (2004) applied the lowest current speed value $\left(0.01 \mathrm{~m} \mathrm{~s}^{-1}\right)$ to validate the model in a conservative approach. During the study, an electronic current meter was used to measure current velocities at several areas of Patos Lagoon estuary characterized by low hydrodynamics (Freitas 2003). In the present study, however, current velocity data used in the model were measured weekly at the control point.

TABLE I

Current velocity $\left(\mathrm{m} \mathrm{s}^{-1}\right)$ at the control points located $100 \mathrm{~m}$ away from the pens at the Porto do Rei and Coreia bays on different sampling dates.

\begin{tabular}{ccc}
\hline Sampling dates & Porto do Rei bay & Coreia bay \\
\hline 1 & 0.076 & 0.070 \\
2 & 0.040 & 0.120 \\
3 & 0.047 & 0.040 \\
4 & 0.055 & 0.039 \\
5 & 0.039 & 0.083 \\
6 & 0.008 & 0.064 \\
7 & 0.012 & 0.082 \\
8 & - & 0.047 \\
9 & - & 0.050 \\
10 & - & 0.060 \\
11 & - & 0.071 \\
12 & - & 0.055 \\
13 & - & 0.070 \\
\hline
\end{tabular}

Building The Mathematical Model

The model in this study (Fig. 3) was based on the one proposed by Castello et al. (2008), which used six parameters: stocking density, nitrogen content of shrimp, total feces, nitrogen excretion, nitrogen losses and total nitrogen. 


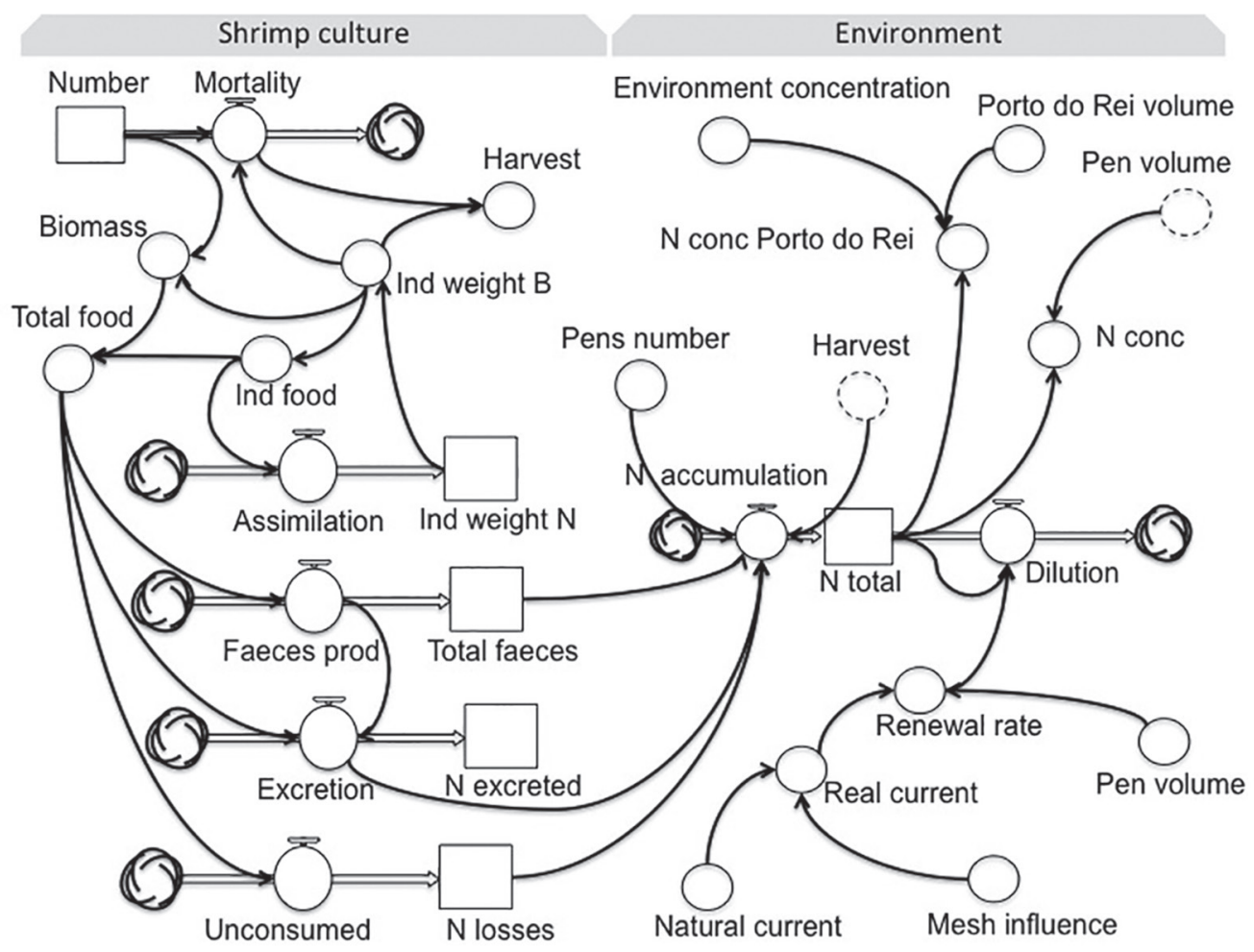

Figure 3 - Model used to estimate the maximal number of pen enclosures that could be installed at the Porto do Rei bay, Patos Lagoon estuary, Brazil.

\section{Model CALIBRATION AND VALIDATION}

To calibrate the model, information on the culture of L. vannamei was employed, but to adjust the model for $F$. paulensis, the modifications suggested by Poersch (2004) in relation to the feeding rate were used together with field-collected data. Data on shrimp growth, mortality and serial data of nitrogen concentrations in the water at Porto do Rei and Coreia bays provided the information to validate the model. In both cases, pen enclosures were stocked with $60,000 \mathrm{~F}$. paulensis post-larvae.

The accuracy of the model was assessed through a correlation between predicted (simulated) values of nitrogen released from the pens at days 1, 30, 60 and 90 and mean values observed of water samples collected $5 \mathrm{~m}$ away from the pens by Poersch et al. (2007).

Results were then submitted to statistical analysis that produced a correlation factor (r) of 0.99 , which indicates that the parameters evaluated were strong enough to reproduce the processes of nitrogen production, consumption and release. Thereafter, new simulations were performed to determine the maximal number of pens that the system can support.

\section{Model Simulations}

The scenario created to estimate the largest number of pens was as close as possible to actual ones. However, care was taken to assure an ecological conservative scenario. Simulations were performed for both bays using a range of current velocities, total water volumes, net influence and clogging effect. Nevertheless, nitrogen concentration values were the same for both sites, since the data was based on the historical record from another bay at the Patos Lagoon estuary.

The main parameter used to determine the total number of pens deployed at the studied bay was a predetermined nitrogen maximal concentration 
of $0.07 \mathrm{mg} \mathrm{L}^{-1}$. This value is based on the Brazilian legislation for nitrogenous compounds in salt waters as defined by CONAMA (Brazil's National Environment Council) resolution 357 (CONAMA 2005).

The time unit applied was days (DT=1), with a total time period of 120 days. The Euleriano integrating method was applied (Swartzam and Kaluzny 1987). The simulations for the Coreia bay show that it is possible to install 29 ( $0.3 \mathrm{ha}$ ) pen enclosures if current velocity is $0.01 \mathrm{~m} \mathrm{~s}^{-1}$ and net clogging effect is $40 \%$. Considering the same current velocity and a clogging effect of $20 \%$, it would be possible to deploy up to 41 pen enclosures at that bay. At these hypothetical circumstances, the total nitrogen concentration of $0.07 \mathrm{mg} \mathrm{L}^{-1}$ would not be reached. With a current velocity of $0.02 \mathrm{~m} \mathrm{~s}^{-1}$ and $0.04 \mathrm{~m} \mathrm{~s}^{-1}$ and a net clogging effect of $40 \%$, the simulation shows the possibility of installing 285 pens or 509 pen enclosures, respectively.

Figure 4A shows the worst scenario for Porto do Rei bay, with a current velocity of $0.01 \mathrm{~ms}^{-1}$ and a net clogging effect of $40 \%$. Considering a stocking density of 20 shrimp $\mathrm{m}^{-2}, 39$ pen enclosures ( 0.3 ha each) would be possible at this area.
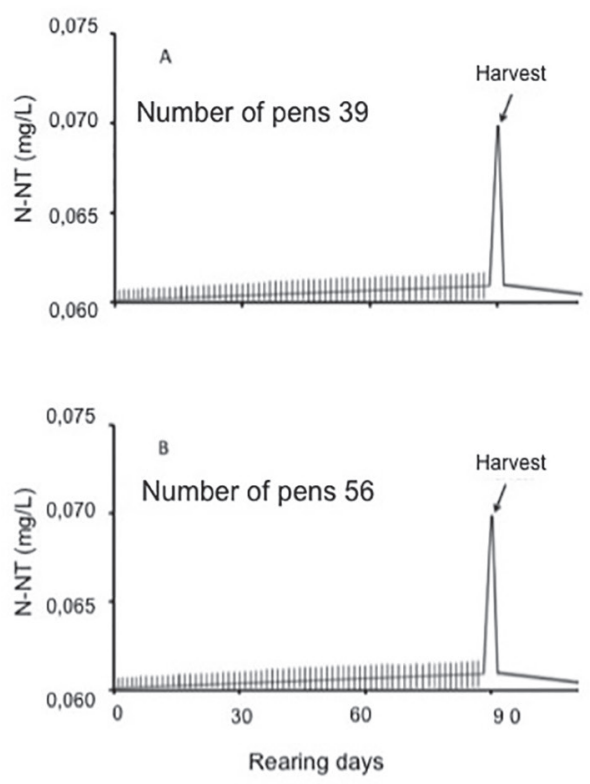

With lower current velocities, higher net influence effect, higher clogging effect and a greater number of pens installed, the highest limit for total nitrogen would be exceeded, compromising the production cycle, the surrounding aquatic environment and the sustainability of the activity. As an example, figure 5 shows the result for 750 pens at the Porto do Rei. In this case, a nitrogen concentration of $0.07 \mathrm{mg} \mathrm{L}^{-1}$ would be reached after 55 days of culture (arrow).

Figure 4B illustrates a scenario where the current velocity would be $0.01 \mathrm{~m} \mathrm{~s}^{-1}$ and the net clogging effect $20 \%$. Under these conditions, the simulation indicates the possible installation of 56 pen enclosures. Should the current velocity be increased to $0.02 \mathrm{~m} \mathrm{~s}^{-1}$ and the net clogging effect to $40 \%$ (Figure 4C), 363 pens could be deployed. For a current velocity of $0.035 \mathrm{~m} \mathrm{~s}^{-1}$ and a net clogging effect of $40 \%$ (Figure 4D), the simulation shows the possibility of installing 683 pens without reaching the predetermined nitrogen concentration value.

According to CONAMA'S resolution 357 (CONAMA 2005) salt and brackish water bodies
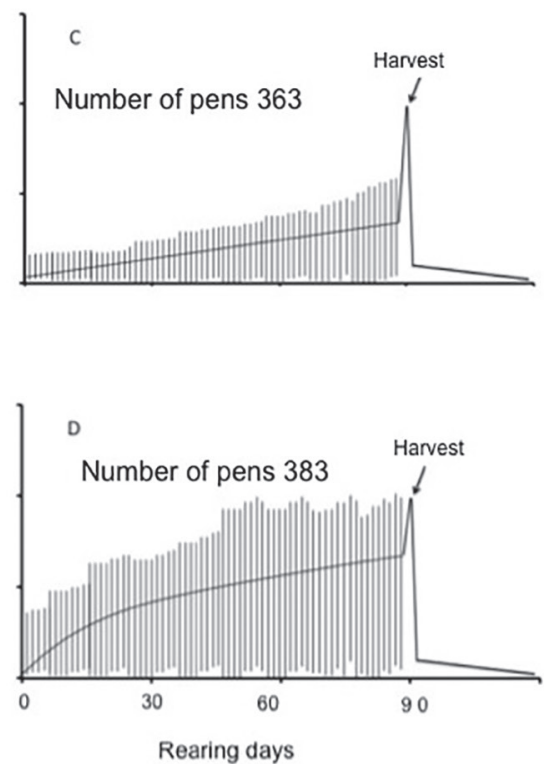

Figure 4 - Influence of the number of pens on total nitrogen concentration at the Porto do Rei bay. A - current velocity of $0.01 \mathrm{~m} \mathrm{~s}^{-1}$ and net clogging effect of $40 \%$; $\mathbf{B}$ - current velocity of $0.01 \mathrm{~m} \mathrm{~s}^{-1}$ and net clogging effect $20 \%$. C and D - current velocities of 0.02 and $0.035 \mathrm{~m} \mathrm{~s}^{-1}$, respectively, and net clogging effect of $40 \%$. 


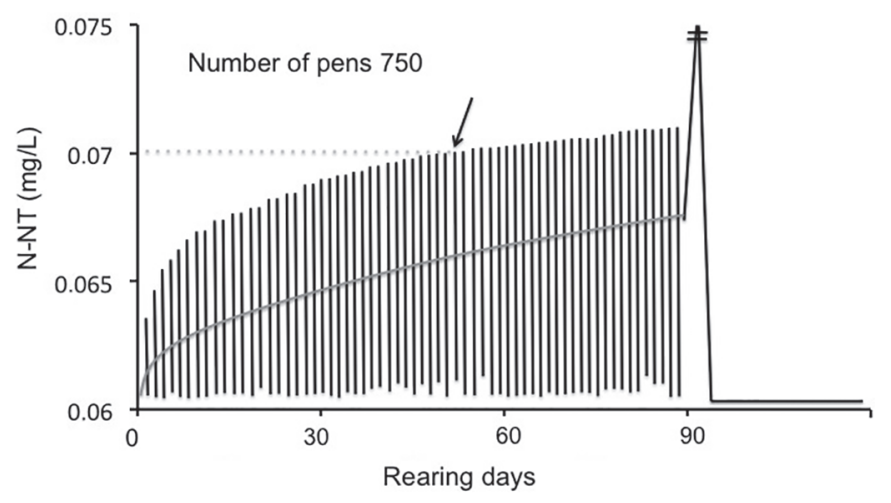

Figure 5 - Effect of the installation of 750 pen enclosures at the Porto do Rei bay on the total nitrogen concentration assuming a current velocity of $0.01 \mathrm{~m} \mathrm{~s}^{-1}$ and a net clogging effect of $40 \%$.

are divided into several classes, with aquaculture activities being class 1 . The upper limits of total ammonia nitrogen, nitrite and nitrate concentrations for this type of water are $0.4 \mathrm{mg} \mathrm{L}^{-1}, 0.07 \mathrm{mg} \mathrm{L}^{-1}$. $0.4 \mathrm{mg} \mathrm{L}^{-1}$, respectively. Therefore, the present upper limits for total nitrogen concentration are well below the values determined by law, suggesting no environmental risk in terms of nitrogeneous compounds. Furthermore, it characterizes the present model as conservative and shows that shrimp pen culture can be developed in a sustainable way.

It is also relevant that the model was developed considering the use of artificial diet as the main source of food for shrimp, eliminating the variability of the results derived from the use of fishery rejects and natural food items. The food composition provided for a culture system will determine the quality and quantity of the effluents released. Since artificial diets tend to have a more stable composition, it allows a more accurate estimate of the nutrients released to the environment and the development of better management practices to reduce food losses, as they are considered the main source of nutrients (Islam 2005).

In the present work, the use of ecological modeling to simulate diverse culture situations allows for the development of management strategies to minimize the release of nitrogenous compounds to the environment. The study contributes to the understanding of the dynamics of semi-intensive shrimp culture systems and the evaluation of management practices (Gomez-Galindo 2000).

Lorenzen et al. (1997) described that the reduction of total ammonia concentrations in aquaculture ponds is correlated with water renewal rates. The same correlation may be established for open culture systems, hence the importance of water circulation through the culture units, which is linked with the current velocity. Therefore, models that consider current velocity data, i.e. parameters that reflect the ecosystem dynamics, produce more pertinent results. Since at the Patos Lagoon bay the current velocity values are highly variable throughout the day (Asmus 1984), the use of more conservative current velocity values to feed the model is recommended. Additionally, the net clogging effect caused by fouling may further reduce current velocity inside the pens. Therefore, values of a current of $0.01 \mathrm{~m} \mathrm{~s}^{-1}$ and net clogging effect of $40 \%$ are considered conservative values to estimate the number of pens.

An important aspect related to shrimp culture systems is the daily water renewal rate employed. In open culture systems rates are dependent on the current velocity, while in closed semi-intensive culture systems, like earthen ponds, daily water renewal rates are usually not higher than $15 \%$. 
The data presented in the present work has demonstrated that aquaculture researchers must apply a more holistic approach. Culture systems should not be considered as an isolated component, but as an important element of the ecosystem. The management practices applied are determinant for the sustainability of the entire system.

Through the use of the proposed model it was possible to simulate different scenarios based on the nitrogen flow and determine the results of the interaction between the culture system and the natural environment. This may serve as a basis for the development of future research about the effects of nitrogen upload in the sediment, and also to estimate the consequences of other anthropogenic inputs of nitrogen to the aquatic environment.

\section{CONCLUSIONS}

Due to the interest in the development of pen shrimp culture in a conservative way, to avoid environmental damages, and considering the highly variable hydrodynamics of the Patos Lagoon estuary, results of the proposed model suggest the maximal installation of 39 ( $0.3 \mathrm{ha})$ pens at the Porto do Rei bay and 29 pens at the Coreia bay. Deploying this number of pens, a total of 13.3 and 18.0 metric tons of shrimp may be produced at the Coreia and Porto do Rei bays, respectively.

Management practices employed at different culture sites may be evaluated through the application of the model presented here, serving as a guide for the development of research and policy for marine aquaculture development, and also as a tool to reduce possible environmental impacts associated with the release of nitrogen. However, other variables must be considered to help decisionmaking, and new simulations must be performed for a better understanding of the system.

\section{ACKNOWLEDGMENTS}

The authors acknowledge the help of Arion Kurtz, Milton Asmus, Tatiana Silva, Rita Veiga and Emily
Johnson. We also thank the Conselho Nacional de Desenvolvimento Científico e Tecnológico (CNPq) (CT-Hidro) and the European Community (AQUAS INCO-CT-2005-015105) for financial support. L. Poersch, R.O. Cavalli, W. Wasielesky, O. Muller and J.P. Castello are research fellows of CNPq.

\section{RESUMO}

Modelos ecológicos têm sido utilizados como ferramenta para avaliar potenciais impactos ambientais causados pela aquicultura. Neste trabalho, foi aplicado um modelo matemático para estimar a quantidade máxima de unidades de produção (cercados com $3.100 \mathrm{~m}^{2}$ ) do camarão-rosa Farfantepenaeus paulensis que podem ser instalados em duas baías rasas no estuário da Lagoa dos Patos (conhecidas como Coreia e Porto do Rei), sem efeitos significativos sobre a qualidade da água e viabilidade do sistema de engorda. Para calibrar o modelo, informações sobre a criação de Litopenaeus vannamei e F. paulensis, bem como dados de campo (influência de material de pano, a velocidade da corrente da água e concentração de nitrogênio) foram utilizados. Considerando um cenário ruim, velocidade da corrente da água de 0,01 $\mathrm{m} \mathrm{s}^{-1}$ e um efeito de colmatação da malha de $40 \%$, seria possível instalar no máximo 29 cercados na baía Coreia e 39 na baia Porto do Rei. Os resultados indicam que o modelo foi útil para determinar o número máximo de unidades de produção que podem ser instalados nestes compartimentos e, portanto, tem o potencial para se tornar uma ferramenta importante na definição de estratégias de gestão ambiental, em relação ao desenvolvimento da aquicultura.

Palavras-chave: nitrogênio, camarões em cercados, sustentabilidade, modelo ecológico, manejo costeiro.

\section{REFERENCES}

ASMUS ML. 1984. Estrutura da comunidade associada a Ruppia marítima no estuário da Lagoa dos Patos, Rio Grande do Sul, Brasil. Tese de Mestrado. Universidade Federal do Rio Grande, RS, Brazil, 132 p. (Unpublished).

BARBIERI RC AND OSTRENSKY A. 2002. Camarões Marinhos: Engorda. Ed. Aprenda Fácil. v.2. Viçosa, MG, Brasil, $320 \mathrm{p}$. 
BAUMGARTEN MGZ AND NIENCHESKI LF. 1990. O estuário da Laguna dos Patos: variações de alguns parâmetros físico químicos da água e metais associados ao material em suspensão. Ciênc Cult 42: 390-396.

Bonilha LEC AND Asmus ML. 1994. Modelo ecológico do fitoplâncton e zooplâncton do estuário da Lagoa dos Patos, RS. Publ Academia de Ciências do Estado de São Paulo 87: 347-362.

BOYd CE AND TEICHERT-CODDINGTON. 1995. Dry matter, ash and elemental composition of pond-culture Penaeus vannamei and Penaeus stylirostris. J World Aquacult Soc 26: 88-92.

BunTING SW. 2001. Appropriation of environment goods and services by aquaculture: A reassessment employing the ecological foot print methodology and implications for horizontal integration. Aquac Res 32: 605-609.

Burford MA, CONSTANZO SD, DENNISON WC, JACKSON CJ, Jones AB, MCKInNON AD, Preston NP AND TrotT LA. 2003. A synthesis of dominant ecological processes in intensive shrimp ponds and adjacent coastal environments in NE Australia. Mar Pollut Bull 46: 1456-1469.

BURFORD MA AND LORENZEN K. 2004. Modeling nitrogen dynamics in intensive shrimp ponds: the role of sediment remineralization. Aquaculture 229: 129-145.

Castello JP. 1985. La Ecologia de los Consumidores del Estuario de La Lagoa dos Patos, Brasil. In: YañesArancibia A (Ed), Fish Community Ecology in Estuaries and Coastal Lagoons: Towards Ecosystem Integration. DR (R) UNAM Press, Mexico, Chap. 17, p. 383-406.

CASTEllo JP AND Möller OO. 1978. On the relationship between rainfall and shrimp production in the estuary of the Patos Lagoon (Rio Grande do Sul, Brazil). Atlântica 3: 67-74.

Castello JP, Poersch L, Vasconsellos MC, Cavalli RO AND WASIELESKY WJ. 2008. Rearing shrimps in Pens: a predictive model for impact assessment. Estuar Coast 31: 215-222.

Cavalli Ro, Wasielesky WJ, Peixoto S, Poersch LHS, SANTOS MHS AND SoARES RB. 2008. Shrimp farming as an alternative to artisanal fishermen communities: the Case of Patos Lagoon, Brazil. Braz Arch Biol Technol 51(5): 991-1001.

ClarK JR. 1996. Coastal Zone Management. Lewis Publishers. New York, NY, 694 p.

CONAMA - Conselho Nacional do Meio Ambiente. 2005. Dispõe sobre a classificação dos corpos de água e diretrizes ambientais para o seu enquadramento, bem como estabelece as condições e padrões de lançamento de efluentes, e dá outras providências. Resolução n 357 , de 17 de março de 2005. Available at http://www.mma.gov. br/port/conama/res/res05/res35705.pdf

D'INCAO F AND REIS EG. 2002. Community based management and technical advice in Patos Lagoon estuary (Brazil). Ocean Coast Manage 45(8): 531-539.

D'INCAO F, VALENTINI H AND RODRIGUES LF. 2002. Avaliação da pesca de camarões nas regiões sudeste e sul do Brasil 1965 - 1999. Atlântica 20: 103-116.
EstaÇão METEOROLÓGICA DA FURG. 2006. Dados de direção do vento medidos pela estação automática. Available at http://www.meteorologia.furg.br/estaut/est-med2.php

FALCONER R AND HARTNETT M. 1993. Mathematical modeling of flow, pesticide and nutrient transport for fish-farm planning and management. Ocean Coast Manage 19: 37-57.

FreitAS DM. 2003. Bases técnicas para o planejamento espacial da atividade de cultivo de camarão em cercados no estuário da Lagoa dos Patos (RS). Tese de Mestrado. Universidade Federal do Rio Grande, RS, Brasil, 230 p. (Unpublished).

FUNGE-SMITH SJ AND BRIGGS MRP. 1998. Nutrient budgets in intensive shrimp ponds: implications for sustainability. Aquaculture 164: 117-133.

GODDARD S. 1996. Feed Management In Intensive Aquaculture. New York, Chapman \& Hall, New York, NY, 194 p.

GomeZ-GaLindo C. 2000. A nitrogen-based assessment of aquaculture: Shrimp farming in northwest México. $\mathrm{PhD}$ Thesis. University of British Columbia, $135 \mathrm{p}$.

Hall poj, Holby O, Kollberg S and Samuelsoon MO. 1992. Chemical Fluxes and mass balances in a marine fish cage farm. IV. Nitrogen. Mar Ecol Progr Ser 89: 81-91.

HARGREAVES JA. 1998. Nitrogen biochemistry of aquaculture ponds. Aquaculture 166: 181-212.

ISLAM MS. 2005. Nitrogen and phosphorus budget in coastal and marine cage aquaculture and impacts of effluent loading on ecosystem: review and analysis towards model development. Mar Pollut Bull 50: 48-61.

JimeneZ-Montealegre R, Verdegem MCJ, VAN DAM A AND Verreth JAJ. 2002. Conceptualization and validation of a dynamic model for the simulation of nitrogen transformations and fluxes in fish ponds. Ecol Model 147: 123-152.

KISHI MJ AND UCHIYAMA M. 1995. A three-dimensional numerical model for a mariculture nitrogen cycle: Case study in Shizugawa Bay, Japan. Fisheries Oceanogr 4: 303-316.

Lefebvre S, Bacher C, Meuret A And Hussenot J. 2001. Modeling approach of nitrogen and phosphorus exchanges at the sediment-water interface of an intensive fishpond system. Aquaculture 195: 279-297.

LORENZEN K, STRUVE J AND COWAN VJ. 1997. Impact of farming intensity and water management on nitrogen dynamics in intensive pond culture: a mathematical model applied to Thai commercial shrimp farms. Aquac Res 28: 493-507.

Lourenço So, Barbarino E, De-Paula JC, Pereira los AND MÁrquez UML. 2002. Amino acid composition, protein content and calculation of nitrogen-to-protein conversion factors for 19 tropical seaweeds. Phys Res 50: 233-241.

MÖller OO AND CASTAING P. 1999. Hydrographical Characteristics of the Estuarine Area of Patos Lagoon $\left(30^{\circ} \mathrm{S}\right.$, Brazil). In: Perillo GME, Piccolo MC and Quivira MP(Eds), Estuaries of South America. Their Geomorphology and Dynamics, Berlin: Springer-Verlag, p. 83-100. 
Möller OO, Castaing P, SAlomon JP And Lazure P. 2001. The Influence of Local and Non-Local Forcing Effects on the Subtidal Circulation of Patos Lagoon. Estuaries 24: 297-311.

Möller OO, CAstello JP AND VAZ AC. 2009. The effect of river discharge and winds on the interannual variability of the pink shrimp Farfantepenaeus paulensis production in Patos Lagoon. Estauaries and Coasts 32: 789-796.

Monteiro IO, Pearson ML, Möller Jr OO And Fernandes EHL. 2005. Hidrodinâmica do Saco da Mangueira: mecanismos que controlam as trocas com o estuário da Lagoa dos Patos. Atlântica 27: 87-101.

Montoya RA, Lawrence AL, Grant WE And Velasco M. 1999. Simulation of nitrogen dynamics and shirmp growth in an intensive shirmp culture system: effects of feed and feeding parameters. Ecol Model 122: 81-95.

ODUM EP. 1983. Ecologia. Guanabara Koogan. Rio de Janeiro, Brasil, $434 \mathrm{p}$.

POERSCH LH. 2004. Aquacultura no estuário da Lagoa dos Patos e sua influência sobre o meio ambiente aquático. $\mathrm{PhD}$ thesis, Biological Oceanography. Universidade Federal do Rio Grande, RS, Brazil, 147 p.

Poersch LH, Castello JP, Wasielesky WJ and CaValli RO. 2007. The challenge of sustainable aquaculture: effects on the environment of the Patos Lagoon estuary. J Coast Res 47: 130-135.

PRIMAVERA JH. 1993. A critical review of shrimp pond culture in the Philippines. Reviews Fisheries Sci 1 151-201.

Reis EG, Vieira PC AND DuARTE VS. 1994. Pesca artesanal de teleósteos no estuário da Lagoa dos Patos e costa do Rio Grande do Sul. Atlântica 16: 69-86.
SEELIGER U AND KJERFVE B. 2001. Coastal marine ecosystems of Latin America. Berlin, Springer-Verlag, 360 p.

SWARTZMAN GL AND KALUZNY SP. 1987. Ecological simulation primer. Macmillan Publishing Company, New York, $370 \mathrm{p}$.

ViadeIRo JR RC, CUNnINGHAM JH, SEMmens KJ AND TIERNEY AE. 2005. Effluent and production impacts of flow-through aquaculture operations in West Virginia. Aquac Eng 33: 258-270.

WASIELESKY WJ. 1999. Produção do Camarão Marinho Penaeus paulensis no Sul do Brasil: Cultivo em Estruturas Alternativas. In: Oceanos: Fontes de Alimentos. Prêmio Jovem Cientista 1997, CNPQ, Fundação Roberto Marinho, Grupo Gerdau, p. 53-106.

WASIELESKY WJ. 2000. Cultivo de Juvenis do Camarão Rosa Farfantepenaeus paulensis (Decapoda-Penaeidae) no Estuário da Lagoa dos Patos: efeitos dos parâmetros ambientais. Doutorado em Oceanografia Biológica. Universidade Federal do Rio Grande, RS, Brasil, 199 p.

Wasielesky WJ, Peixoto S, Jensen L, Poersch LH AND BIANCHINI A. 2004. Estudo preliminar do cultivo do camarão-rosa Farfantepenaeus paulensis em cercados no Estuário da Lagoa dos Patos. Bol Inst Pesca 30: 63-70.

WASIELESKY WJ, POERSCH LH, JENSEN L AND BIANCHINI A. 2001. Effect of stocking density on pen reared pink shrimp Farfantepenaeus paulensis (Perez- Farfante, 1967) (Decapoda, Penaeidae). Nauplius 9: 163-167. 


\section{APPENDIX}

ANNEX

Equations used to create the mathematical model for the Porto do Rei Bay are detailed below.

$\square$ Ind_weight_N(t) $=$ Ind_weight_N(t - dt $)+($ Assimilation $) * d t$

INIT Ind_weight_N $=0.01$

INFLOWS:

Ю Assimilation $=$ Ind_food $* 0.16 * 0.3 * 0.85 * 0.25$

$\square \mathrm{N} \_$excreted $(\mathrm{t})=\mathrm{N}$ _excreted $(\mathrm{t}-\mathrm{dt})+($ Excretion $) * \mathrm{dt}$

INIT $\mathrm{N}$ excreted $=0$

INFLOWS:

ЮExcretion=total_food* $0.3 * 0.16 * 0.85$-(faeces_prod + total_food* $0.3 * 0.16 * 0.85 * 0.25$ )

$\square \mathrm{N} \_\operatorname{losses}(\mathrm{t})=\mathrm{N} \_$losses $(\mathrm{t}-\mathrm{dt})+($ unconsumed $) * \mathrm{dt}$

INIT N_losses $=0$

INFLOWS:

O Unconsumed $=$ total_food $* 0.3 * 0.16 * 0.15$

$\square \mathrm{N} \_t$ total $(\mathrm{t})=\mathrm{N} \_$total $(\mathrm{t}-\mathrm{dt})+\left(\mathrm{N} \_\right.$accumulation - dilution $) * \mathrm{dt}$

INIT N_total $=0$

INFLOWS:

Ю $\mathrm{N} \_$accumulation $=\mathrm{IF}($ harvest $=0$ ) THEN (number_pens* (Excretion)) ELSE(number_pens* (excretion+total_faeces $+\mathrm{N} \_$losses $)$)

OUTFLOWS:

Ю Dilution $=\mathrm{N}$ _total $*$ renewal_rate

$\square$ Number $(\mathrm{t})=$ number $(\mathrm{t}-\mathrm{dt})+(-$ mortality $) * \mathrm{dt}$

INIT Number $=60000$

OUTFLOWS:

Ю Mortality $=\operatorname{IF}($ Ind_weight_B $<9) \operatorname{THEN}(0.002 *$ number $)$ ELSE(number)

$\square$ Total_faeces $(\mathrm{t})=$ Total_faeces $(\mathrm{t}-\mathrm{dt})+($ Faeces_prod $) * \mathrm{dt}$

INIT Total_faeces $=0$

INFLOWS:

Faeces_prod $=$ Total_food $* 0.3 * 0.16 * 0.85 * 0.1$

$\bigcirc$ Biomass $=$ Number*Ind_weight_B

$\bigcirc$ Conc_N_Porto do Rei $\mathrm{mg} \mathrm{L}^{-1}=(\mathrm{N}$ _total/Porto_do_Rei_volume $)+$ Environment_conc

$\bigcirc$ Environment_conc $=0.065$

$\bigcirc$ Harvest $=$ IF $($ Ind_weight_B $<9)$ THEN $(0)$ ELSE $($ Mortality*Ind_weight_B $)$

$\bigcirc$ Ind_Food $=0.56^{*}\left(\right.$ Ind_weight_ $\left.\mathrm{B}^{\wedge}-0.5\right)$ 
$\bigcirc$ Ind_weight_B $=$ Ind_weight_N/0.0285

$\bigcirc$ Mesh influence $=0.6$

N_Concentration $\mathrm{mg} \mathrm{L}^{-1}=\mathrm{N} \_$total $/$Pen_volume $\mathrm{m}^{3}$

$\bigcirc$ Natural_current $\mathrm{m} \mathrm{s}^{-1}=0.01$

Number_pens $=39$

$\bigcirc$ Pen_volume $\mathrm{m}^{3}=3000$

Porto_do_Rei_volume $\mathrm{m}^{3}=8720000$

$\bigcirc$ Real_current $=$ Natural_current $\mathrm{m} \mathrm{s}^{-1} *$ Mesh_influence

$\bigcirc$ Renewal_rate $=\left(90 *\right.$ Real_current*86400) $/$ Pen_volume $\mathrm{m}^{3}$

$\bigcirc$ Total_food $=($ Ind_Food*Biomass $) * 0.0285$ 